\title{
Psaltical Modes - Meanings and symbolics
}

\section{Domin ADAM*}

Abstract: The Universe of Byzantine music is a profound one, that is why every side should be analysed for getting to the essence of psaltical soul of the singing. Every sign has a certain meaning, every mode has a certain composition and every singing genre is interpreted in a certain way. It is important to search and analyse the historical evolution of every of the mentioned categories for being able to form a holistic image about what Byzantine music meant and means.

Keywords: music, psaltical, bizantine, mode, eh, octoeh

\section{Introduction}

I will not make a historical radiography of the voices, but I will make a brief presentation of the Byzantine or psaltic modes in order to discern the meanings and symbolism of the voices. Often we sing or listen the church's psaltic voices but we can't pervade beyond what the voices seem. They are much more than just a song, but to pervade these meanings and symbolisms we need much dedication and leaning on the sacred. They were made with a certain sense, not only for the pleasure

* Rev. PhD, Ass.Prof. Domin Adam, Faculty of Orthodox Theology at "1 Decembrie 1918" University, Alba Iulia, Romania. 
of being listened but also to feed the soul. I will refer to this more in the present study.

Christian worship is born in the Jewish faith and we observe how the Savior and his disciples give great attention to the worship of the Great Temple in Jerusalem and to the song practiced here (not giving old or new testamentary arguments). Thus, there is in the song of the first Christians a transfer of the Jewish worship song, but the new Christian song will develop and enrich more and more because of those who were converted and who were part of foreign nations other than the $\mathrm{Jew}^{2}$.

Psaltic religious voices (and generally the religious music) have as main objective the creation of a silent atmofere favorable to meditation. The interpreter is required to avoid any exaggeration, that would figure something else than the holy. In fact, it is the purpose of church's music: to address the soul, as well as some musical genre address the body or the reason. This music should be, should become, "the music of the angels" (at this level must be reached the unity between the heavenly and the earthly), to be sung in such a way as to create a proper atmosphere for reflection, meditation and real meeting with God in the Church.

The voices give birth to a different feeling in every soul; sometimes we can deduce from them the doxological song, prayer, strengthening of the faith, sometimes the spiritual joy.

\section{Summary}

Byzantine Music is an art of prayer, of spirituality, it is a part of the Church's worship and a spiritual fact in the life of every Christian, because through it, is glorified God.

St. Vasile cel Mare in his homily to the youth speaks about the psycho-educational and therapeutic value of the music and shows that any voice or manner (eh), especially dorian, of the music (let's say: Byzantine-laic) has a certain characteristic and effect on the human

${ }^{2}$ Elena Moraru-Saviuc, Worship music as segment of eternal music, Oradea, Editura Scriptum, 2008, p.26. 


\section{Psaltical Modes - Meanings and symbolics}

psyche $^{3}$. The variety of feelings created by the Byzantine music brings in the most practical way, peace in the soul.

First Ehul voice or voice I Doric begins rising on PA (D) brings in the human's soul the feeling of glorifying God. This is the voice that defines the music in the category of arts, because, as St.Ioan Damaschin said: "Of all (voices) you have the first victory." 4 The first voice brings the hope of salvation to humans, because it creates a sense of strength and of steadiness, is full of optimism and melodiously.

The second Ehul or the second voice - FRIGIC voice starts ascending from VU (E) brings in the human's soul the feeling of gratitude, because it makes us be thankful for all that God gives us. Listening to the second voice, one becomes gentle and quiet, and this ehul is a starting point on the path of communication between God and human.

The third Ehul or the third voice - LIDIC voice, start ascending from GA $(\mathrm{F})$ is characterized by simplicity, strength, and awakens in us a feeling of endless joy and secret hope. This is a voice of the march. ${ }^{5}$

The fourth Ehul or the fourth voice - MIXOLIDIC voice, starts ascending on DI $(G)$ awakens in human the feast feeling. There is no wonder that at the two major holidays, Ascension of the Holy Cross and Sunday of the Holy Cross (Lent) which are strictly holidays of resurrection through the cross, the doxology is sung on the fourth voice. Likewise, in the Annunciation and in the Entrance of Theotokos in the Church the ninth song is also played on the fourth voice.

The fifth Ehul (plagal of the first voice) or the fifth voice EOLIAN voice starts ascending on the $\mathrm{KE}(\mathrm{A})$ and is characterized as a voice of lamentation. It creates a complaint together with joy and makes human to give God a request prayer. Upon hearing this voice we feel deep down joy repentance and rebirth and personal resurrection. Not without sense were ordained certain chants of Resurrection (Tropar

${ }^{3}$ Vasile cel Mare, XXII Homily towars youngs, în P.S.B., partI, Translated by Dumitru Fecioru, nr.17, București, Editura IBMBOR, 1986, pp. 575-576.

4 Ioan Damaschin, http://www.doxologia.ro/terapie-pentru-suflet/muzica-dreptrugaciune-arta-terapie,traducere Lucian Filip, apud http://www.johnsanidopoulos. com/2013/10/byzantine-music-as-art-of-music-and art.html, accesat la: 04.08.2014.

${ }^{5}$ Ibidem. 
Christ is risen, and other chants from the Easter's Sunday) to be sung on the fifth voice, but just in order to emphasize the passage from death to life, from the Cross to the Resurrection and the sorrow and pain to joy and good humor.

The sixth Ehul (plagal of the second voice) or the sixth voice LOCRIAN voice, starts ascending from $\mathrm{ZO}$ (B) and brings a total joy, is characterized by love for God, by hope and it is a mistic eh; humble, softens the human's soul and renews it in a new life.

The seventh Ehul (plagal of the third voice) or the seventh voice - IONIAN voice, begins ascending from NI (C) and is characterized by being grave, hard. It planted in our souls the feeling of eagerness and tiredness on the spiritual path, is like a march of hosts, as St.Ioan Damaschinul said.

The eighth Ehul (plagal of the fourth voice) is also a voice of celebrating festive cadenced voice, flowing and encouraging.

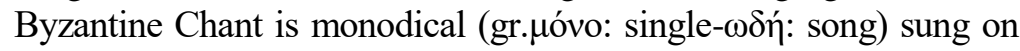
one voice, and the song is the element of expression. The Byzantine chant expresses the paramountey of God and is accompanied by a continuous sound with the same height, called accompaniment (gr.íoov equal), which gives the byzantine's monody a comparison with the golden fund of icons. The accompaniment symbolizes God's omnipresence and is like a soundtrack of a film, one soundtrack of the entire existence.

For a theology of the Byzantine musical semiography we have as a landmark the Treaty of Michael Blemmydes, aboute who had written several byzantinologists including the most famous, who is Nicolae Gheorghita from National University of Music Bucharest.

The Byzantine musical universe doesn't allow to be understood the fact that what the protopsalter "commits" is accidental. Any utterance, even an intonation formula (apechema), invokes Christ and His help: by this term-ananeanes- $\alpha v \alpha$ val $\alpha v \varepsilon \varsigma$ is shown the introduction into them (eh) and means "Truly, God has forgiven me!"

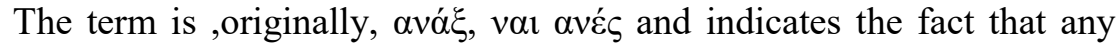
start, start from / and with God and ends just in God. ${ }^{6}$

${ }^{6}$ The Hagiopolites-A Byzantine Treatise on Musical Theory, Preliminary edition by Jorgen Raasted, Copenhague 1983,p.123. 


\section{Psaltical Modes - Meanings and symbolics}

Michael's Blemmydes Treaty is the only work that addresses trenchant the semography of the Byzantine music from theological perspectives.

Each voice or eh, before singing has an introduction formula in the melodic mood of the voice that intones a singer slowly, before the beginning of the $\operatorname{song}^{7}$; all treaties of the theory of psaltic music include these formulas of introduction. It is about the summative creation of the melodic character of the voice, enabling the interpreter to sing the song noted on Neum. In the song without Neum (oral) ${ }^{8}$, just the text applied on the melody of the voice, generally it is not used formula of introduction. The benchmarks in this type of song are melodies learned before on a known text, usually a sticheron, singing a hymn or another, they are the melodic patterns containing inside the atmosphere and the character of the voice.

With the crystallization of Christian worship, it appears the first musical genre. Each of them have a specific meaning. For example: katavasia means descent - when katavasia was sung the two church pews came down in the middle, under the chandelier, and hence, standing, sang the song 9 . The kontakion - is a solemn hymn that tells the essence of the feast, therefore it was necessary to be marked. The enlightening was sung when it was day, towards the end of Matins (when it was night), etc., including the names of their signs have meaning and purpose in Greek: ison-law, oligon-less, petasti-throws, chendima-embroidery, epistrophe-return, elafron-light iporoi-drain, hamil-low, clasmă-sharing, gorgon-fast, applicable-simple, argonslowly, variable -heavy, omalon-brill, antichenoma-time relents start again, psifiston-each syllable, to choose between them, eteron-other, endofron-meditation, interior [Frosini-thinking], ifes-calming, soothing [ifes-standing facing down], [ephesus-appeal, agitation], sticheron-

7 Grigore Panțiru, The notation and ehs of the byzantine music ,București, Editura Muzicală, 1971, p.211.

${ }^{8}$ Grăjdian Vasile, Elements of Church cant and types, Sibiu, Editura Universității "Lucian Blaga", 2002, p. 56.

${ }^{9}$ Dictionary of musical terms , București, Editura Enciclopedică, 2010, p. 100. 
alignment, ghost-line of words, irmos-which must be heirmologionchain, i.e. legatto, agem-neplin, ftora-sticare etc.

Of all genres, features and symbolisms of the voices we deduce the savior role of the Byzantine art psaltic music. Byzantine church music calms the hearing, humbles the heart and elevates the mind, so its purpose and character is saint ${ }^{10}$. These voices are composed of everything that can bring our salvation and have always had the objective to renew and restore the human. God left us the legacy to full our hearts, to feel safe, without needing other type of music that leads to the degradation of our souls ${ }^{11}$.

Music is of eternal significance because the Heavenly Father's throne is surrounded by consonant harmonies. We just need to find the color of this harmony and resonate with it, otherwise the harmonic sounds of music becomes distorted and thus the music becomes not music even harm our soul and psyche. God originally gave us the music in order to glorify the Trinity and to help the human in his own exaltation in spirit. And after the fall, the music also had a supportive role of lifting the human; new situation, new role. We do not know how the edenic music was, but we think it was a particularly beautiful since the devil always seeks to pervert it. And this Pepelea of the music managed to attract people towards the distructive music, to sounds which have reverberations that attract people and destroy them, or like the sticky bands that say "attract and kill" substantially certain types of music destroy human's psychological system, slowly, surely and irreversibly.

At the Christ's Birth angels sang an unheard song: Glory to God in the highest and on earth peace, good will toward men" (Lc.2, 14). Probably this is the song of the heaven's inhabitants. The heaven's music, the music of the Celestial Spheres is one continuous, smooth, as is the music of nature on earth (a glimpse from the beauty of the spheres' music). The music of the spheres and the music of nature is one without rhythm and without a tonal center of gravity within the meaning we give today, a song we would say in unison (though the

${ }^{10}$ Iacob Yameos, The principal aspects of the history of church music (translation by Luca Mirea), Alba Iulia,Editura Reîntregirea, 2012, p.42.

${ }^{11}$ Ibidem. 


\section{Psaltical Modes - Meanings and symbolics}

term is vague and relative to what we mean). The music of nature and of celestial spheres is like an accompaniment whose position changes from time to time into a dominant position for harmony. ${ }^{12}$

This song in unison was borrowed by man to express his different feelings, but in a cadenced, rhythmic way (crucially dependent on the feeling expressed through music) and with a starting point, a landmark, with musical intervals smaller or larger but without being theorized or extremely problematized (the documents are very few from those times removed). The music in unison is found in all antiquity, in all nations and in all cultures and spiritualities, at the Hebrew and at the Christians of the first millennium. Then appears the polyphony and the harmonic music, but they are not the subject of this study.

The early Christians borrowed from the Hebrew the type of song chant solo, refrenar, antiphonal etc. The songs of biblical inspiration adopted by Christians and sung in the mentioned manners in the Jewish religion, were the subject of an extensive musical development within Christian worship. First psalms, hymns and finally spiritual songs made the concern of the Christians in the first centuries in the cult.

The space with the strongest mark on the Christian worship was the Hellenistic space - Greek was the language of propagation - here there had already existed a musical culture, musical concerns etc. Here were crystallized the first musical genre: tropar, kontakion, dogma, thanks to the genius, wisdom and inspiration of the melodists. Then observable are the kinds of interpretation: irmological or troparian tact, sticherarion and dandelion. Each of these tacts have a certain sense: the tropar is the cadenced walking toward the eternal kingdom, the sticherion suggests the approach of the kingdom's peace and dandelion songs (cherub, Chinon) mean contemplation, smelling the scent of the Kingdom.

From now on we can already speak about the Byzantine music, name received from the capital of the Greek Empire; it is a music that represents "the highest expression of the gracious, orthodox

12 To research the study on ison: "Ethos of the byzantine music" written by Emanuel Cristian Cercel. 
theology ${ }^{13}$ ", a doxology music and a music of spiritual elevation ${ }^{14}$. This new music wil be framed in modes, meaning ehs, as in antiquity, but had nothing in common the new modes with the ancient Greek modes (ancient Doric with medieval Doric etc.), only the names. Victor Giuleanu and Victor Iuşceanu in their treaty of music say that the medieval modes have nothing in common with the ancient ones because "the medievals took the wrong terminology of the Greek modes, which were descending, applying it to scales with ascending melodic signification" 15 . Extending the Christianity from the Jewish in the Hellenistic space, the new musical religious creations came into connection with the ancient Greek modes: DORIAN- E (E, D, C, B, A, G, F, E) FRIGIAN-D, LIDIAN -C, MIXOLIDIAN-B, HIPODORIANA, HIPOFRIGIAN-G, HIPOLIDIAN - F which sang descending.

In XVI century the voices sits different. It sets out a number of 7 modes and are ordained in the order that they naturally appear on the musical staircase $\mathrm{C}$ major: Mode $\mathrm{I}=$ Ionian $($ mode $\mathrm{C}$ ); Mode $\mathrm{II}=$ Dorian $($ mode D); Mode III = Frigian $(\operatorname{mode} E)$; Mode IV = Lidian (mode $\mathrm{F})$; Mode $\mathrm{V}=$ Mixolidian $(\mathrm{G}$ mode); Mode $\mathrm{VI}=$ EOLIAN $($ mode $\mathrm{A})$; Mode VII = Locrian $($ mode $\mathrm{B})$. The modern theory on the popular diatonic modes uses these seven medieval names. ${ }^{16}$

In the crystallization process of the byzantine music contributed several factors: Hebrew songs, the Greek musical culture, the neumatical musical notation and the fact that Byzantium was the most important center for the spread of the musical culture, culture that will be called Byzantine. In the political, cultural and theological center of Constantinople came to study monks from throughout the known world, including Pope Gregory the Great, who led the musical culture of Byzantium in the area which he came from. First Ambrose of Milan speaks about four main modes (they were probably already known

13 Elena Chircev, Confessions and dialogues about Byzantine music Cluj-Napoca, Editura Risoprint, 2013, p.136.

14 Constantin Secară, Byzantine music -doxology and spiritual uplift, Bucharest, Editura Muzicală, 2006.

${ }^{15}$ Ibidem, p.136.

16 V.Giuleanu, V. Iușceanu, Threaty of music's teory , București, Editura Muzicală, 1962, p.138. 
Greek modes, but untheorized), then Gregory adds another four secondary. Gregory influenced by the Byzantine modes, modes organized in eight ones (octoehs) ${ }^{17}$ studied during his linger in the capital of the Byzantine Empire, took over the system organized into eight ehs, ${ }^{18}$ would be led in the West by the future Pope Gregory where it would be named system modes, built ascending: Dorian started on D (D-E-F-G-A-B-C-D) FRIGIAN - E, LIDIAN -F, MIXOLIDIAN - G, EOLIAN-A, LOCRIAN- B.

The first four of these modes will be called own ehs, authentic ${ }^{19}$ or rents ${ }^{20}$, principal or independent.

- $\quad$ First Eh named prostheses (DORIAN), from the PA (RE) and symbolized the air;

- $\quad$ The second was called deuterus (FRIGIAN), from the VU (MI) and symbolized the earth;

- $\quad$ The third called Trita (LIDIAN), began on GA (note F) and symbolized water;

- $\quad$ The fourth was called tetartos (MIXOLIDIAN), began on DI $(\mathrm{G})$ and symbolized the fire.

The Byzantine ehs, as ancient modes, received names of ancient Greek cities: Doria, Lydia, Frygia, Milet, which in ancient times had a special melodic character. In the Middle Ages (early) the songs' character had nothing in common with the ancient melodic characters nor with the organization of sounds: the ancient modes were descending and the medieval modes were ascending.

In ancient times the modes settled the stretching of the song ${ }^{21}$ and had, wore itself the following characters or symbolisms:

-Mode I Dorian-VU (E); - this mode was considered a warrior, energetic, serious;

\footnotetext{
${ }^{17}$ Octoeh-eight modes, ehs or voices.

18 Grigorios Th. Statis, The charm of the past and present musical byzantine art, translation from gr.by Florin Cătălin Ghiț (Masterclass of byzantine music on Mănăstirea Nicula-Final night-byzantine concert preceded by a conference), September2013, in Tabor Magazine, Cluj-Napoca, Anul VII, nr.12, December.

19 Authentes (gr.) speak by itself, something that stands out and can not be questioned.

${ }^{20}$ Chirii (gr.) has the meaning of supreme authority.

${ }^{21}$ Iacob Yameos, op. cit., p.21.
} 
-Mode II Frygian-PA (D);- was considered thrilling, passionate, with much pathos

-Mode III Lidian-NI (C); - was considered era socotit melancholic, dreamy, soft;

- Mode IV Mixolidian-ZO (B) ${ }^{22}$ - was considered full of tension, agitation, unstable.

The character of these descending ancient modes are no longer met today. Popular modes or ecclesiastical modes (ascending) carries other characters that I mentioned above. For practical reasons the ehs or modes are called and noted with Roman numerals (as in the case above) or Arab. As a structure the gregorian modes are different from the byzantines, they olny borrow the name ${ }^{23}$.

In addition to these four authentic voices, the Greeks were counting four more modes, ehs, that derived from the genuine ones. They started with a quint below and wore before the Plaghios ${ }^{24}$ prefix:

-Eh V Plaghios Protos-PA- DI descendent (base on DI);

-Eh VI Plaghios Deuteros-VU-KE (base on KE);

-Eh VII Plaghios Tritos-GA-ZO (base on ZO);

-Eh VIII Plaghios Tetartos-DI-NI (base on NI).

It is used the prefix Hypo ${ }^{25}$ for derived modes, or Hyper ${ }^{26}$ if they were made at the upper octave (mode V Hypodorios, mode VI Hypolydios, mode VII Hypofrygios, mode VIII Hypomixolydios).

The musical greek mode of thinking, as I said, will be taken in the West by Pope Gregory the Great (the second half of the VI century) that stayed for years as ambassador in Constantinople, sent by Pope Pelagius II; model scales will be used for 12 centuries by Westerners. This modal system is composed by scales and ranges which are structured differently from the later tonal system - tones and midtones are arranged differently in the major and minor known by us. It is

22 The forth is named mylitios-citadel of Milet from Asia Minor-the same with the byzantine mixolidic.

${ }^{23}$ Victor Giuleanu, The byzantine melodic, București, Editura Muzicală, 1981, p.27.

${ }^{24}$ Plaghios-plagal.

${ }^{25}$ Hipo (gr.)- means down, under, below.

${ }^{26}$ Hyper (gr)- means above, up. 
richer system than the tonal, in the stairways and number ranges, but also this system, as the tonal one has a tonal center.

The tonal system has given us the possibility of using two natural diatonic modes: Major natural- IONIAN MODE medieval become C Major and the minor natural, EOLIAN MODE - A minor (with variants $)^{27}$. On JS Bach's time the foundations temperate tone, with the starting point in the medieval modes, ehs organized by a specific system which belongs to G. Zarlino ${ }^{28}$ (untempered system) ${ }^{29}$. The modal system, in addition to Ionian and Eolian mode, still has five natural diatonic modes: DORIAN, FRIGIAN, LIDIAN, MIXOLIDIAN and LOCRIAN, as the modes came from their changing with chromatic elements.

A recognition of the importance of the inexhaustible source of the rich musical thesaurus affirms the composer Camille Saint-Saëns, who says that the music goes to archaic modes. He provided the direction of the musical art, showing that the domination of majorminor will fall and that the popular modes and oriental ranges will come into the musician's attention; what is really happening ${ }^{30}$.

\section{Conclusion}

If in literature we do detailed analyzes to understand and properly use all its forms in everyday speech, in the same way we must analyze, explain and use correctly the senses and the meanings of all musical elements.

Nowadays we see more and more celebrities on television, or in church singers, protopsalters who that think if they have voice they know everything, but it is not enough the talent if you're not looking to interpret the deepest meanings of the music. Therefore any interpretation requires to be studied and interpreted according to the meanings, symbology and styles; a return to the these will give the church's chant a new breath.

${ }^{27}$ V. Giuleanu, V. Iușceanu, Threaty of the music theory, op.cit. , p.129.

${ }^{28}$ Giosetto Zarlino-teoretician and italian composer(1517-1590), takes the teories of Aristoxene din Tarent (sec.IV î.d.H).

${ }^{29}$ V.Giuleanu, V. Iușceanu, op.cit., p.142.

${ }^{30}$ Victor M. Iușceanu, Modes and scales, (apud Camille Saint-Saëns, The history of the universal music), București, Editura Muzicală, 1960, p.64. 
A summative conclusion of this study is the following: each psalm or eh has its character (therefore it must be considered as such), each voice has a special intonation and fluency given by the three tracks which have the meaning mentioned above. All these combined will give a sense to the psalm singing, so beautiful melos of the Orthodox Church.

\section{References:}

1. Elena Moraru-Saviuc, Worship music as segment of eternal music, Oradea, Editura Scriptum, 2008.

2. Vasile cel Mare, XXII Homily towars youngs, în P.S.B., part. I, (Translated by Dumitru Fecioru), nr.17, București, Editura IBMBOR, 1986.

3. Ioan Damaschin, http: //www.doxologia.ro/terapie-pentrusuflet/muzica-drept-rugaciune-arta-terapie, traducere Lucian Filip, apud http://www.johnsanidopoulos.com/2013/10/byzantine-music-asart-of-music-and-art.htm.

4. The Hagiopolites-A Byzantine Treatise on Musical Theory, Preliminary edition by Jorgen Raasted, Copenhague 1983.

5. Grigore Panțiru, The notation and ehs of the byzantine music,București, Editura Muzicală, 1971.

6. Grăjdian Vasile, Elements of Church cant and types, Sibiu, Editura Universității "Lucian Blaga", 2002.

7. Dictionary of musical terms, București, Editura Enciclopedică, 2010.

8. Iacob Yameos, The principal aspects of the history of church music (translation by Luca Mirea), Alba Iulia,Editura Reîntregirea, 2012.

9. Elena Chircev, Confessions and dialogues about Byzantine music Cluj-Napoca, Editura Risoprint, 2013.

10. Constantin Secară, Byzantine music-doxology and spiritual uplift, Bucharest, Editura Muzicală, 2013.

11. V.Giuleanu, V. Iușceanu, Threaty of music's teory, București, Editura Muzicală, 1962.

12. Victor Giuleanu, The byzantine melodic, București, Editura Muzicală, 1981.

13. Victor M. Iușceanu, Modes and scales, (apud Camille SaintSaëns, The history of the universal music), București, Editura Muzicală, 1960. 